\title{
“'Wy3e, welcum iwys to pis place!' Emotions in the schemas for arrival, return and welcome at the Arthurian court
}

\author{
Carolyne Larrington
}

'Willkommen, bienvenue, welcome! / Fremder, étranger, stranger!'1 What could be more positive an emotion than the warmth which medieval social custom demands that the court extends to the newcomer to its midst? The quality of a welcome is crucial to institutional and individual reputation, to the very idea of courtesy as constitutive of and inherent within the ideal court. ${ }^{2}$ The major feast days, in particular 'the hyghe feste of Pentecoste' as Malory describes it, demand the attendance of the Order of the Round Table and unknown persons, Arthurian texts imply, are particularly welcome to present

\footnotetext{
1 'Willkommen', from the musical Cabaret, lyrics by F. Ebb. Orig. production 1966.

${ }^{2}$ For discussion of conventions of welcome in twelfth- and thirteenth-century British contexts, see J. Kerr, 'The Open Door: Hospitality and Honour in Twelfth / Early Thirteenth-Century England', History, 87 (2002), 322-35 and J. Kerr, “'Welcome the coming and speed the parting guest": hospitality in twelfth-century England', Journal of Medieval History, 33:2 (2007), 130-46. The texts under discussion in this article date from later than the period which Kerr considers, but the obligations of hospitality remain unchanged. For a useful contextualization of feast-customs in medieval England, see D. Brewer, 'Feasts', in A Companion to the Gawain-Poet, ed. by D. Brewer and J. Gibson, Arthurian Studies XXXVIII (Cambridge: D. S. Brewer, 1997), pp. 131-42.
} 
themselves at court then. ${ }^{3}$ Indeed, one constant in Arthurian literature across medieval languages and periods is the king's demand that something remarkable must eventuate before dinner can be served, a custom that invites adventure and highlights 'the interdependence of knightly prowess and courtly display' in the feasting context. ${ }^{4}$ This expectation often cues the appearance of a stranger who brings some marvel, presents himself with theatrical flair or who confronts and challenges the court. Such visitors emphasize an Otherness which, as Aisling Byrne comments, 'widens the focus of the narrative from the microcosm of the court to the world beyond and usually constitutes an invitation to quest and adventure. ${ }^{5}$ Emotions ranging from joy to mild surprise to anxiety, even fear, are registered by the tale's characters at the guest's arrival. Cognition too comes into play as the court assesses and interprets the social meaning of the newcomer's appearance, for perception and affect are closely related in medieval models of emotion. ${ }^{6}$

${ }^{3}$ All Malory references from Sir Thomas Malory, Le Morte Darthur, ed. by P. J. C. Field, Arthurian Studies LXXX, 2 vols (Cambridge: D. S. Brewer, 2013), 1: 98; further references given in text.

${ }^{4}$ See A. Byrne, 'Arthur's refusal to eat: ritual and control in the romance feast', Journal of Medieval History, 37 (2011), 62-74 (p. 68). This article is a thoughtful discussion of the origin and persistence of the custom in Arthurian romance,

${ }^{5}$ A. Byrne, 'The Intruder at the Feast: Negotiating Boundaries in Medieval Insular Romance', Arthurian Literature, 27 (2010), 33-57 (p. 34).

${ }^{6}$ See C. Saunders, 'Mind, Body and Affect in Medieval English Arthurian Romance', in Emotions in Medieval Arthurian Literature: Body, Mind, Voice, ed. by F. Brandsma, C. Larrington and C. Saunders (Cambridge: D. S. Brewer, 2015), pp. 31-46. 
Derek Brewer observes that, 'the feast is the expression of a certain social dynamism, whereby tensions and even conflict are built in and contained. ${ }^{7}$ Yet the stimulus to begin the feast, the newcomer's appearance, can exacerbate those existing tensions and foreground the Round Table's complacency or arrogance. The 'invitation to adventure' identified by Byrne challenges the court to open itself to an outsider and allow its claims to pre-eminence to be probed. The anxiety that such confrontations provoke is embodied by the divisive figure of Kay the Seneschal, whose hostile snap judgements are an important element of the welcome schema. ${ }^{8}$ The text's audience also must decide whether the convention of the hopeful would-be recruit or the disturbing intruder at the feast is in play, by interpreting the emotional behaviours of all involved. ${ }^{9}$ Anticipation, excitement, wonder, and alarm are transmitted from characters to audience; for the romance adventure begins here.

When the established knight comes home to the court different emotions, as we shall see, come into play. The returning knight is generally welcomed back to a

\footnotetext{
${ }^{7}$ Brewer, 'Feasts', p. 141.
}

${ }^{8}$ Space does not permit discussion of Kay's changing roles within the welcome and incursion convention. See L. Gowans, Cei and the Arthurian Legend (Woodbridge: Boydell and Brewer, 1988) for a wide-ranging overview of his appearances. In summary, whether he impetuously demands and unsuccessfully undertakes an adventure (most spectacularly in Le chevalier de la charette) (pp. 50-51), scoffs at untried yet noble knights such as Gareth or La Cote Male Taille (pp. 46-7; 119; 142-4 or (when himself a guest) behaves churlishly to the Carl of Carlisle (pp. 139-40), his response is consistently to be understood by the audience as situationally inappropriate. ${ }^{9}$ See Byrne, 'The Intruder'. 
community which is eager to hear about his adventures and share in his reflected glory. But the knight's return - conditioned by the demand that he narrate his adventures truthfully - can be clouded by ambiguity and regret. Thus the welcome back, as much as the welcome, evokes a set of emotions within the courtly community that intersects powerfully with the chief enterprise of the Arthurian court: the production and maintenance of collective and individual honour with their clear potential for generating pride, joy, and shame within the courtly context. The welcome back announces the successful conclusion to adventure or it signals an ambivalent and disturbing outcome, particularly in the earlier sections of Malory's Morte Darthur where the newly constituted chivalric community is climbing a steep learning curve. Outside the world of the text, satisfaction, admiration, or alternatively, doubt and unease are produced and shared among the 'emotional subcommunities' of romance audiences. ${ }^{10}$ Varying interpretations and literary judgements are shared and discussed within group settings, where the reactions of other audience members cue social appraisal and

10 The terms 'emotional communities' and 'emotional subcommunities' are of course Barbara Rosenwein's. See most recently B. Rosenwein, Generations of Feeling: A History of Emotions, 600 -1700 (Cambridge: Cambridge University Press, 2016): 'Emotional communities are groups - usually but not always social groups - that have their own particular values, modes of feeling, and ways to express those feelings ... Larger communities will contain variants and counterstyles- "emotional subcommunities" if you will.' (p. 3). Whether we can posit an 'emotional community' of romance consumers across languages and over time is beyond the scope of this essay. On the social nature of emotion, see B. Parkinson, 'How Social is the Social Psychology of Emotion?', British Journal of Social Psychology, 50 (2011), 405-13. 
activate both emotional and cognitive responses to the text. The emotional economy of romance thus includes character and audience, in-text and real-world feelings and opinions about chivalry as social practice, here focussed through the schemas of welcome and welcoming-back.

The welcome encounter is a fraught one. Who is the newcomer? What does he want? Does his arrival enhance or threaten the honour of the court? And for the guest himself: Will I be welcomed and gain the boon that I ask? Will I be accepted into the court and allowed to join the knightly community? What kinds of values and customs prevail in this hall? Sir Gawain and the Carl of Carlisle offers an examination of the challenge faced by a trio of Arthurian men in a hall where a single principle - obedience to the wishes of the Imperious Host - holds sway. ${ }^{11}$ Early medieval wisdom poetry, and its later cousin, courtesy literature, has much to say on the ways of managing the individual's presentation at and integration into a larger social group. ${ }^{12}$

${ }^{11}$ Sir Gawain and the Carle of Carlisle, in Sir Gawain: Eleven Romances and Tales, TEAMS Middle English Texts (Kalamazoo: Medieval Institute, 1995)

http://d.lib.rochester.edu/teams/text/hahn-sir-gawain-sir-gawain-and-the-carle-ofcarlisle\#49. Viewed January $25^{\text {th }} 2016$.

${ }^{12}$ See Kerr, 'The Open Door': 'The prudent host, therefore, exercised caution to guard against those who were a potential danger, for ... the outsider was an unknown quantity and it was necessary to convert the hostis to a hospes, the stranger to a friend', (p. 331). For a summary of medieval courtesy-poems, see J. W. Nicholls, The Matter of Courtesy: Medieval Courtesy Books and the Gawain Poet (Woodbridge: Boydell and Brewer, 1985), 
The conventions of the welcome schema are well established across Arthurian romance, so much so that normative welcomes are rare. The significant variations in the realization of the welcome scenario generate anticipation both within the court and the romance audience. Generally, newcomers enter the hall on foot where the court is waiting for the feast to begin. Often witholding their name, they ask for a boon. The king responds courteously, invites them to join the feast, and frequently moves to grant the boons and close the episode before eating commences. Once established, the tradition of awaiting the marvel opens the community to opportunities for adventure through its standing invitation to new arrivals to make themselves known at the court, even to demand admission to the Round Table. This ritual is fraught with emotional uncertainty: for the king, the court and the one who arrives. While the theatrical staging of the newcomer's entrance serves to manage anxiety on the part of the new arrival, it intensifies emotions of wonder, surprise and fear for court insiders.

In-group and out-group identities are strongly at stake in the scenario of arrival, welcome and response; the newcomer must decide how to stage himself so as to maximize his impact on the group, while the court, both collectively and individually, react to and interpret the arrival performance. ${ }^{13}$ It is here, crucially, that we can see cognitive and emotional processes in action: in negotiating these primary encounters with the Other. As long as the newcomer witholds his name and stages his difference especially pp. 179-90. More broadly, see Medieval Conduct, ed. by K. M. Ashley and R. M. A. Clark (Minneapolis: University of Minnesota Press, 2001). ${ }^{13}$ For a useful overview of in-group and out-group identities, their formation and modification, see D. Abrams and M. A. Hogg, Social identifications: A social psychology of intergroup relations and group processes (London: Routledge, 2006). 
from the rest of the court, his identity and his value as a potential Round Table member are up for negotiation. Once his name is known, as Frederic Jameson astutely observes, in the chivalric communities of romance the Other almost always proves to be a version of the Same: one who can be successfully be assimilated into the court. '[T] he hostile knight, in armor, his identity unknown, ... tells his name ... at which point he becomes simply one knight among others and loses all his sinister unfamiliarity.'14

A well-staged entrance acts to capture the court and the king's attention in a kind of captatio benevolentiae. It increases the chances that the boon will be granted, and the newcomer eventually accepted into this knightly community. So Gareth, in Malory's 'Tale of Sir Gareth' stages his arrival with a minimum of ritual:

And so Sir Gawayne, a lytyll tofore the none of the day of Pentecoste, aspyed at a wyndowe thre men uppon horsebak and a dwarfe uppon foote. And so the thre men alyght, and the dwarff kepte theire horsis, and one of the men was hyghar than the tothir tweyne by a foote and an half. Than Sir Gawayne wente unto the kyng and sayde, 'Sir, go to your mete, for here at hande commyth strange adventures.' (I:223) It might be thought, with some justification, that being very tall is not particularly remarkable, but Gareth intensifies the self-consciousness of his presentation by coming into the hall leaning on the shoulders of his companion, 'he fared as he myght nat go nothir bere hymself but yf he lened uppon their shuldyrs' (I:223). This is enough to silence the court - 'there was made peas and rome' (I:223) - and Gareth is allowed to approach the dais, whereupon he pulls himself upright and stretches to his full height before asking for his three boons. Gareth manages this entrance very well: he does not 14 F. Jameson, 'Magical Narratives: Romance as Genre', New Literary History, 7 (1975), 135-63 (p. 161). 
try to astonish the court with magical devices or outré displays, rather he signals that he is not as he might appear at first sight and that he intends to hold back revelation of his identity, lineage and prowess until such time as suits him. Gareth's theatricalization of identity, initially staging the Self as Other, taps into notions of spectacle and opens up the question of how his appearance is to be read: whether as hostile or as merely intriguingly unexpected - apparent inability to walk unaided looks like a disqualification for knighthood. This generates attention and interest, compounded by the paradoxically unknightly request merely, for the moment, 'that ye woll geff me mete and drynke suffyciauntly for this twelve-monthe' (I:224). The odd request does nothing to dispel Arthur's correct belief that he will 'preve a man of ryght grete worshyp'; when Beaumains (as Kay christens him) asks for the fulfilment of his two other boons a year later, Arthur has no hesitation in granting them. Gareth's spectacular performance is then resumed; a dwarf brings word that his horse and armour 'in the rycheste wyse' await him, and 'there wente many aftir to beholde how well he was horsed and trapped in cloth of golde' (1:227). Gareth elicits wonder and respect, except in the eyes of that perennial misreader of appearances, Kay, who makes the mistake of pursuing and challenging his former kitchen boy and who, as is traditional in Kay-jousting episodes, is easily bested. Thus Gareth's Otherness represents only an enhanced version of Sameness, one eager to define itself as emphatically not the same as his brothers already at court, but which nevertheless confirms his worthiness to join the Round Table. ${ }^{15}$

\footnotetext{
15 See C. Larrington, 'Sibling Relations in Malory's Morte Darthur', Arthurian Literature, 28, 57-74 (pp. 63-8) for discussion of Gareth's project of differentiation from his brothers.
} 
To Gareth's successful exploitation of the conventions of welcome we may contrast the position of Balin, who started on quite the wrong foot with Arthur (as his prisoner) and who 'wente pryvaly into the courte and saw thys adventure whereoff hit reysed his herte' (I:49). The adventure in question is the arrival of a damsel girt with a mysterious sword that causes her 'grete sorrow and comberaunce' (I:47). When no one present at court can remove the encumbering sword from its scabbard, Balin sees his chance to put himself forward, for, as a 'poore knyght and poorely arayde' (I:49), at first he dares not volunteer. His success changes his status utterly in the eyes of the court and draws a handsome apology from the king for having overlooked him. Balin replies with equal courtesy. Now that he has distinguished himself so remarkably the king extends a formal, if belated, welcome: 'ye shall be ryght wellcom unto me and to my barownes and I shall amende all mysse that I have done agaynste you' (I:50). Balin's moment in favour does not last long, thanks to his own impetuosity and perhaps the curse placed on the sword, but he shows how the unregarded knight can capitalize on the marvel schema to draw positive attention to himself, to be accepted into the court and to win promises of favour from the king. If the newcomer-knight does not stage an adventure, getting a proper welcome and being noticed by the king is evidently difficult. Balin's experience resonates with contemporary courtly anxiety about the processes of achieving royal favour. ${ }^{16}$

\footnotetext{
16 See C. S. Jaeger, The Origins of Courtliness - Civilizing Trends and the Formation of Courtly Ideals - 939-1210 (Philadelphia: University of Pennsylvania Press, 1985), in particular pp. 82-100.
} 
The entry into Camelot of the Green Knight in Sir Gawain and the Green Knight has been much analysed. The Green Knight, styled by Morgan le Fey for her own purposes, rides into the court and directly up to the high table. He bears contradictory tokens of peace and threat, and is entirely green - a colour whose associations range from the diabolic to the elvish to the natural. ${ }^{17}$ So strange, so paradoxical are the signals he gives off that the court does not know in the slightest how to read him; he too pretends that he does not know how to read the court, rolling his eyes, asking rudely without formal greeting, 'Wher is ... pe gouernour of pis gyng?' (ll. 225-6); he 'con studie' the guests to discover 'Quo walt per most renoun' (1l. 230-1) - as if the king on the dais were invisible. ${ }^{18}$ The Green Knight is staging an obvious performance to make his rhetorical, and ultimately, political point: that the young Round Table's reputation is not self-evident, that its youthful king is hard to pick out from the other knights 'in her first age' (1.54), and that that renown is about to be put to the test. Astonishment and wonder are key elements in the welcome sequence, but the court seems too stricken by amazement. Those who are standing press closer to the knight to stare at him - 'Ther watz lokyng on lenpe' (1. 232) - and many a noble man was ar3e (l. 241) to answer him: an extremely loaded word, given its implications of cowardice, even effeminacy. The Knight's emotional unsettling of the court works to shade their wonder into something more akin to fear: an affective move which signals embarrassement and shame as

\footnotetext{
${ }^{17}$ See D. Brewer, 'The Colour Green', in A Companion to the Gawain-Poet, pp. 181-90. 18 Sir Gawain and the Green Knight, in The Poems of the Pearl Manuscript: Pearl, Cleanness, Patience, Sir Gawain and the Green Knight, ed. by M. Andrew and R. Waldron, $5^{\text {th }}$ edn (Exeter: Exeter University Press, 2007). Subsequent line references in text.
} 
possible outcomes of the welcome encounter. These emotions are indeed paramount in Gawain's final view of himself at the poem's end, even if the court does not share them.

The poet times nicely his relation of the silence that greets the Green Knight's question; the hush lasts across a stanza break and the poet plants in the audience's mind that, although the court's quietness seemed as if they had fallen asleep, not all of them held back because of doute (uncertainty, anxiety), but some 'for cortaysye' (courtesy) (ll. 246-7). This is the first hint that courtesy will be crucial in resolving the awkwardness created by the arrival, both immediately and in the poem's large plot. The courtiers are enabled by their understanding of courtesy in a collective response: waiting to take their cue from the king. Arthur now pronounces words of welcome, and politely invites the knight to dismount, to join in the feast and afterwards to make known his errand. The Green Knight brusquely declines, using the familiar pronoun to address the king. Cortaysye and 'Sir cortays kny3t' (ll. 263; 276) are deployed by Green Knight and by Arthur with an insulting edge, and, earlier, by the narrator to bring into question the implications of the court's lack of response (1l. 246-7). Once the errand is declared, more embarrassing silence ensues, until Arthur takes it upon himself to accept the challenge. In a virtuoso display of courtesy, Gawain nimbly enters the scene, relieving the king of the risk involved in the adventure and taking it upon himself.

It is clear in this scene that all involved - king, court, Gawain and guest - are well aware of the rituals involved in welcome, and that the deliberate subversion of these, primarily on the part of the Green Knight, is, as he will later admit, a staged performance, intended to lure a representative of the Camelot in-group into taking up the challenge which will test the individual's moral standing and the Order's renown. The failures - or at least the delay - in the court and king's performance of the welcoming ritual suggest that there is some lack in the youthful chivalric brotherhood's understanding of what 
constitutes honour, and this will indeed prove to be the case. The poem's opening scene establishes a clear in-group identity, busily involved in cohesive rituals of New Year giftgiving; these activities are suspended as the court waits for the marvellous occurrence: an interval which invites them to reflect on their purpose as a chivalric community (namely, to pursue adventure). The outsider who challenges their norms is alarmingly unreadable and quite unassimilable into their community. Unlike the many knights whose first contact with the Round Table comes about in the context of just such an adventure and who afterwards join the Order, at the end of this romance Bertilak heads off '[w]hiderwarde-so-euer he wolde' (1.2478). Neither he nor his female allies are to be incorporated into the Arthurian chivalric order; and thus, perhaps, the inadequacies of the welcome performance at Camelot do not finally matter.

Galahad's arrival at Camelot is heralded by signs and wonders in both the Queste del Saint Graal and in Malory. These are not of his making but are rather divinely authorized portents: 'And whan they cam unto the ryver they founde there a stone fletynge, as hit were of rede marbyll, and therein stake a fayre ryche swerde.' (I:668). Lancelot's son is introduced to the court by a mysterious 'good olde man and an awnciente' (I:669), as a descendant of Joseph of Arimathea, and of royal lineage; the promise that 'the mervayles of this courte and of straunge realmys shall be fully complevysshed' (I:669) through him draws a warm welcome from Arthur. Once Galahad has taken the Siege Perilous, his name is found, marvellously, to be inscribed on it; the young knight dismisses his escort by asking him to bear greetings back to 'my grauntesyre, Kynge Pelles, and unto my lorde Kynge Pecchere' (I:670). The court 'mervayled gretly' that Galahad dare sit in the Siege Perilous, but they are doubly reassured by the state with which the old man departs (accompanied by twenty noble squires, added by Malory to the Queste-narrative), and by Galahad's obvious high 
breeding. Thus, he embodies the best kind of Sameness: an ideal aspirant to the Round Table, capable of occupying the Siege Perilous and with an impeccable lineage. But if the court thinks it knows how to read him, it is very much mistaken, for his knightly career will radically redefine chivalry, its practice, history, and meaning.

The welcome back of the returning knight follows a rather different schema in which theatricality is not socially desirable. The court's convention, originally enforced by Merlin who wants to ensure that the knights' adventures are committed to writing, whether by Blaise or by the team of clerks that Arthur is said to employ for the purpose, is that the knight must truthfully relate what has happened to him when he has been away from the court. ${ }^{19}$ Just so, Malory notes how Pellinore is sworn 'uppon the foure evaungelistes to telle the trouthe of hys queste from the one ende to that other' (I: 96). His companions in adventure are likewise sworn on their return. The three knights the newly knighted and poorly equipped Torre, his father Pellinore and Gawain - set out on a multiply interlaced adventure to recover the hart, the brachet and the lady who marvellously manifested themselves at Arthur's wedding feast. Torre succeeds handsomely in his first adventure; the king and queen note how well he has done, and Merlin prophesies a glittering future career for him, as a knight who will be 'passyng trew of hys promyse, and never shall he outerage' (I:91).

Gawain by contrast fails; he accidentally slays a lady when refusing to give mercy to her knight and is compelled to bear her body back with him to Camelot, where Merlin

\footnotetext{
${ }^{19}$ For 'the archive at Salisbury, an invented record', see Lancelot-Grail: The Old French Arthurian Vulgate and Post-Vulgate in Translation, trans. N. J. Lacy et al., 5 vols (New York: Garland, 1992-), I: xxviii-xxx (p. xix)
} 
perhaps pointedly advises Arthur to swear Gawain to tell the truth about what has happened. Gawain can hardly fudge the issue with the lady's head hanging about his neck: 'the kynge and the quene were gretely displeased with sir Gawayne' (1:87), and a panel of ladies is invited to pass judgment on him. Gawain must swear a prototype Pentecostal oath before he can be readmitted to the court. Even if the knight's learning trajectory is not clear, the requirement that he narrate his experiences truthfully to the court means that he cannot change or over-dramatize his presentation. In admitting that he ignored the pleas of a distressed damsel standing over the corpse of her lover, Pellinore enables the court to rethink the centrality of service to women as part of their ethos. In these conclusions to the individual knightly adventures of Torre, Pellinore and Gawain the welcome back permits an ethical evaluation of the knights' behaviour, and the court is enabled to to learn and eventually to refine and codify its understanding of chivalry in practice. These early adventures, commented on by Merlin who already knows the details of what has occurred, are critical to the formulation of the Pentecostal Oath, in which the requirement: 'allwayes to do ladyes, damesels, and jantilwomen and wydowes soccour' (I:97) furnishes one of the weightiest clauses: the court stands in urgent need of this ethical emphasis. The convention of swearing the truth of the returner's narrative is now established; later, Ywain, Gawain and the newly recruited Marhaut are also sworn to recount their adventures, 'and the kynge was passynge glad of their commyng, and so was all the courte ... And there was Sir Marhaute well knowyn, for there were knyghtes that he had macched aforetyme' (I:142-3). Without Merlin's interpretative and teaching presence however, it is unclear that feedback to the chivalric community from the knights errant's experiences is now effectively delivered.

The knight does not return unchanged by his experience, as the best-known romance iteration of Gawain indicates. Gawain's narration of his adventure at the end of 
Sir Gawain and the Green Knight strikingly examplifies the convention. Openly emotional as '[b]e nirt in pe nek he naked hem schewed' (1. 2498), he tened, groned, and blushed: '[p]e blod in his face con melle' (ll. 2500-02). Gawain's strongly somatic reactions are ascribed by the poet to 'gref and grame' and 'schame' (as also at l. 2371). The intradiegetic audience - the court - responds to Gawain's feelings with laughter. There has been much debate about whether this is a laughter of incomprehension or a laughter which seeks precisely to understand, to try to reincorporate the unhappy knight into the community and to appropriate his considerable achievement as its own. ${ }^{20}$ The king's comforting of the knight should, I think, be taken at face value; in welcoming Gawain back Arthur once again gives the lead for the court's response to Gawain's highly conflicted emotions.

The absence of any thoughtful or ritualized reincorporation process when Bors and Lancelot and the other knights straggle home from the Grail Quest is telling here; 'than was there grete joy of hym in all the courte' (1:788), Malory observes of Lancelot's return but although 'all thys was made in grete bookes and put up in almeryes at Salysbury' (1:788), there is no sense that the narratives generated by the Grail Quest have any impact on the court's understanding of itself. Lancelot modifies his own behaviour with regard to the queen for a time but, inevitably, falls back into his old ways. The Round Table is no longer able to respond flexibly to the experiences of the returning knight, nor, in contrast to the young court still learning how to be a knightly community, can it revise its ethical positions. The irreducibility of Malory's Gawain's view of knighthood, expressed to a hermit near the start of the Grail Quest, that no

\footnotetext{
${ }^{20}$ Among many other discussions, see M. Stevens, 'Laughter and game in Sir Gawain and the Green Knight', Speculum, 47 (1972): 65-78.
} 
penance is necessary for him 'for we knyghtes adventures many tymes suffir grete woo and payne', (I:691) is emblematic of the court's inability to absorb and assimilate the new paradigms of chivalry which the Quest generates, an incapacity that plays its part in the final catastrophe.

The welcome - and the welcome back - are rituals which contain and channel the anxieties of the court as a community. It is an occasion for a properly social emotion, when the court has to act, as Frank Brandsma has suggested, as an emotional organism, to arrive at a collective interpretation of the meaning of events and spectacle. ${ }^{21}$ The Round Table's responses are sometimes divided - as in Sir Gawain and the Green Knight - yet a closer examination of the motif has yielded some thoughtful and aesthetically interesting variations on the welcome-theme. The welcome explores anxieties for court, newcomer and returner; like many of the positive emotions discussed by other contributors to this issue it is shot through with ambivalence. Matters of personal honour or face, of group identity, and individual expression must all be tactfully managed if the guest is to be assimilated to the knightly Order; humbly putting up with the robust challenges of the discourteous Kay appears to be part of the incorporation ritual. In its encounter with the newcomer the court too must be ready to maintain and demonstrate its commitment to adventure, for, as Byrne notes, 'the feast in medieval culture is already an area of latent threat, an opening onto disorder rather than a refuge

${ }^{21}$ F. Brandsma, 'The Court's Emotions', in Cultures courtoises en mouvement, ed. by I. Arseneau and F. Gingras (Montréal: Presses Universitaires de Montréal, 2011), pp. 7482 
from it'. ${ }^{22}$ The arriving damsel offers occasion for adventure; the newcomer knight or would-be knight challenges the court on a number of levels; the intruder overturns the conventions of the welcome and puts the court on its mettle. All three kinds of arrival foreground the shared values (in particular cortaysye, but also an unified definition of chivalry) prevalent in the chivalric community; these must be negotiated and reassessed when the adventure is over and the knight come back.

For the returning knight brings with him a narrative which helps the court redefine and make more precise its own understanding of chivalric values: to strengthen its group identity. He may also be remarkably changed by his experiences and his reassimilation into the in-group be problematic. Moreover, the community learning derived from the returning knights' tales seems to falter once Merlin is no longer there to summarize the newly gained wisdom. The court's extraordinary capacity to respond to the possibilities of the welcome encounter is epitomized by its final visitor in Malory's book: Sir Urry. This represents the acme of the warm-hearted welcome; everyone at Camelot, led by the king, participates in the communal effort to heal the suffering knight, touching him intimately and praying for him. After this climax of unity, with the gradual implosion of the Round Table, the visitors stop coming, and the knights stop coming back: Lancelot's anticipated return in response to Gawain's death-bed letter comes all too late. As the court endeavours to absorb the ways in which their chivalry interacts with and impacts upon the world external to the court, responding with joy or sorrow to the news from outside, so too the changing medieval audiences of Arthurian romance feel, discuss, and learn from the understandings of aristocratic

22 Byrne, 'Arthur's Refusal', p. 67. 
identity and behaviour that the Arthurian texts alternatively model and problematize for them. 